Before birth - after death

\section{Before birth - after death}

\section{J M Harris}

\section{Editor-in-Chief John Harris discusses the four events that remind us of the concerns about what happens before birth and after death.}

$\mathrm{F}$ our recent events have reminded us that many people are concerned about what happens before birth and after death, even if what happens before birth happens to those who will never be born and even if the near death happenings occur after death and to those who cannot care about them. The recent events involve a decision of the European Court of Human Rights, a decision of the UK Human Fertilization and Embryology Authority (HFEA), a proposal before the UK Parliament and a book by the most famous living German philosopher.

On $8^{\text {th }}$ July 2004 The European Court of Human Rights (ECHR) in Vo $v$ France confirmed the view that the scope of legal principles protecting human individuals does not normally extend to the unborn and that in the words of the court "the unborn child is not regarded as a "person" directly protected by Article 2 of the Convention". (The Convention referred to here is the European Convention on Human Rights and Fundamental Freedoms Article 2 of the European Convention on Human Rights and Fundamental Freedoms and Article 6 of the International Covenant on Civil and Political Rights recognise the existence for all persons of a right to life protected by law). This case has demonstrated once again that the unborn do not generally possess such a legally protected right.

A few weeks later, the HFEA made an important decision (published on the $11^{\text {th }}$ August 2004), which has been reported and discussed worldwide, giving British scientists permission to perform therapeutic cloning using human embryos for the first time. The purpose of the work is to investigate new treatments for conditions including diabetes, Parkinson's and Alzheimer's disease.

Last year Jürgen Habermas ${ }^{2}$ suggested in a new book that genetic modification including gender selection involves curtailing the ethical freedom of future children or involves causing them to suffer a terrible psychological burden of knowledge the effect of which is that such children would "no longer regard themselves as the sole authors of their own life history". ${ }^{3}$

Finally The Human Tissue Bill currently before the United Kingdom Parliament concerns the ethics of using post mortem human tissue and the associated issues concerning the consents that might be relevant.

The first two events, the decision of the ECHR and that of the HFEA, provoked genuine horror from those who, like Josephine Quintavalle of the pro-life group Comment On Reproductive Ethics, believe that "no human life should be sacrificed for the benefit of anybody else, no matter how dramatic the promises are." ${ }^{\prime 4}$ Such a view seems to take the moral high ground and to reject any trade-off between lives. But, so far from rejecting a trade off between lives, the pro-life position actually advocates such a trade-off. It says that in a choice between the lives of embryos and the lives of those whom embryo research might save, it is the embryonic lives that must be protected. The ethics of this way of choosing between lives certainly require more attention.

A different focus on the ethics of either interfering with embryos or indeed choosing between them is the object of Habermas' concern. While we cannot know for certain whether or not Habermas is right about genetic modification or indeed gender selection, we do have a substantial body of related empirical data to call upon. The world over millions of people marry exclusively within their race, cast, religious group or clan. All the resulting children will know that they were chosen, among other things of course, to have features typical of those races, casts clans etc. While there may indeed be some evidence that these practices are harmful, the harm has not been such as to lead to any widely supported prohibition of such practices, at least on the grounds that concern Habermas.

The Human Tissue Bill was provoked by a series of cases of the abuse of retained human tissue and organs, ${ }^{5}$ but deplorable as those abuses were, the proposed remedies risk prioritising the interests of the dead and their relatives and friends over those of the living and their relatives and friends. Both sets of interests command respect and deserve consideration. What is less clear is whether, as the Bill proposes, the interests of the dead (or more realistically of their relatives) should have some sort of priority. This is another example of a case in which we are forced to "tradeoff" or choose between the moral claims of different groups of people and in which priority is claimed for one side of the equation as against the other. What is required is a genuine and painstaking balance of those competing interests and the costs of prioritising one set over another.

J Med Ethics 2004;30:425. doi: 10.1136/jme.2004.010397

Correspondence to: Professor J M Harris, The Centre for Social Ethics and Policy, School of Law, University of Manchester, Williamson Building, Oxford Road, Manchester M13 OJH UK; john.m.harris@man.ac.uk

\section{REFERENCES}

1 The case Vo $v$ France (application no. 53924/ $00)$. For full text of the judgement see www.echr.coe.int.

2 Habermas J. The Future of Human Nature Cambridge, Polity 2003

3 Ibid. pp75-100 (quotation at page 79)

4 Scientists given cloning go ahead. BBC NEWS http://news.bbc.co.uk/go/pr/fr/-/1/hi/health/ 3554474.stm.

5 The Royal Liverpool Children's Inquiry Report. London: The Stationary Office, 30th January, 2001:445 
Medical imaging

\section{The role of medical imaging in the abortion debate}

\section{Kirklin}

\section{Deborah Kirklin discusses the role of medical imaging in the abortion debate}

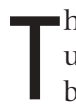
he latest developments in fetal ultrasound technology, made public by a group called Create, ${ }^{1}$ and first introduced to the wider UK public by the Evening Standard newspaper reporter Isabel Oakeshott in September 2003 and again in July 2004, have evoked a flood of responses from the public, pro-life and pro-choice campaigners, and politicians, re-igniting the debate about abortion in the UK and elsewhere. The focus of the Evening Standard articles, on the smiling, walking, and waving babies that the images purport to show, was echoed throughout the worldwide media coverage that followed. In July 2004, Sir David Steel, sponsor of the 1967 Abortion Act, publicly stated that the Create images led him to believe it was time to review the legal time limit for abortions. Prime Minister Tony Blair said he considered calls for such a review reasonable.

What interests me here is the powerful role that biomedical imaging, and the human artifice it involves, can play in influencing the nature, timing, and tone of this debate. The ultrasound technology involved is without doubt impressive. A computer is used to simulate the $3 \mathrm{D}$ appearance of the fetus in the womb by combining a series of $2 \mathrm{D}$ images and then filling in any gaps; the $4 \mathrm{D}$ images are generated by using the simulated 3D images to produce a rapidly changing sequence of images, an illusion of fetal movement is thereby created. The photo gallery on the Create website contains still images (generated by $3 \mathrm{D}$ ultrasound technology) and video clips (generated by 4D ultrasound technology). Two of these video clips are the major source of the controversy that has been generated: one appears to show a fetus smiling repetitively, the other appears to show a fetus waving its hand and forearm back and forward. A third video-clip, not shown on the website, appears to show a fetus walking in the womb. What is not immediately apparent when viewing the video clips is that these video clips are in fact video loops, with the same movement shown again and again. Thus the waving fetus is an illusion created by showing the movement of the fetus' arm, from left to right across its body, over and over again. The smiling fetus, who appears to coyly smile then relax its mouth before coyly smiling again, is also an illusion. We do indeed see the fetus draw back its lips but instead of seeing what happens next, the illusion of smiling is created by the loop presentation of the images.

I am not pointing this out in order to deny the possibility that fetuses are capable of making the movements that these video clips purport to show, a proposition that I find totally plausible. Nor am I suggesting that the producers and distributors of these images set out intentionally to deceive those accessing them. I am, however, very interested in the potential for medically and scientifically generated images to create illusions of this sort, whether intentionally or unintentionally. It seems probable that even small changes in technology might have the potential to influence the nature of human responses to the images generated, and the subsequent decisions and actions taken as a consequence, as evidenced by the media furore that greeted these images and the influence this has had on politicians.

Perhaps unsurprisingly, for those who are pro-life it appears that these images are nothing less than technologically generated visual proof that the unborn child is a living human being'.2 But those claiming that the moral argument against abortion is strengthened by these images thereby leave open the possibility that new information, in this example the role of human artifice in the generation of the Create images, may in turn weaken that very case. Some prochoice advocates have also been tempted to focus on the relevance or otherwise of the apparent ability of fetuses to smile. Ellie Lee, Director of Pro-Choice, has argued that the apparent smile viewed in both the stills and video-clips is not in fact a smile in the sense of the social construct we understand a smile to be, stating that 'Smiling is an activity that has social connotations. To smile requires a degree of self-consciousness and experience of interacting with other people. You do not have to be a genius to work out that a fetus, or indeed a small baby, does not have this. ${ }^{3}$ She then goes on to dismiss the capacity to smile as a significant factor in determining the moral status of the fetus, and states her belief that the reason abortion is sanctioned by society is because of a desire to respect the autonomy of women. If Lee's argument is about respecting the autonomy of women then her argument about when a smile is not a smile is irrelevant. The use of biological discourse in Lee's defence of abortion implies otherwise and prepares the ground for future bio-technically based challenges to her conclusions.

The use of biological discourse to make normative arguments has little to do with intellectual rigour and much to do with politics. The use of medically generated images, and the human artifice that involves, does nothing to improve the quality of the abortion debate and is to be regretted.

J Med Ethics 2004;30:426.

doi: 10.1136/jme.2004.010439

Correspondence to: Deborah Kirklin, Senior Lecturer in Medical Humanities \& Director, Centre for Medical Humanities, Department of Primary Care and Population Sciences, Royal Free and University College Medical School, Archway Campus, 2nd Floor Holborn Union Building, 2-10 Highgate Hill, London N19 5LW, UK; d.kirklin@pcps.udl.ac.uk

\section{REFERENCES}

1 Create. http://www.createhealth.org/ (accessed 6th August 2004).

2 The Pro-Life Party. http://www. prolife.org.uk/ document.asp?id = prbabiessmileinwomb, htm\&se $=2 \& s t=4$ prbabiessmileinwomb, htm\&se

3 Lee E. Behind the 'smile'. http:// www.prochoiceforum.org.uk/ ocr_ethical_iss_1.asp (accessed 8th August 2004). 